\title{
IMPLEMENTASI PERAN MANAJERIAL KEPALA SEKOLAH DI TK FASTRACK FUN SCHOOL DAN TK RUMAH CITTA
}

\author{
Tri Nugroho, Wuradji \\ Program Studi Manajemen Pendidikan PPs UNY, UNY \\ inudtz@gmail.com
}

\begin{abstract}
Abstrak
Penelitian ini bertujuan mengungkapkan penerapan fungsi manajerial Kepala Sekolah TK Fastrack Fun School dan TK Rumah Citta dalam (1) merencanakan program kegiatan sekolah, (2) mengorganisasikan potensi sekolah, (3) menggerakkan personil sekolah, dan (4) mengevaluasi pelaksanaan kerja personil di sekolah. Penelitian ini menggunakan pendekatan kualitatif. Subjek penelitian: kepala sekolah, guru dan karyawan. Pengumpulan data menggunakan metode observasi, wawancara dan dokumentasi. Analisis data menggunakan metode trianggulasi. Hasil penelitian menunjukkan bahwa Kepala Sekolah TK Fastrack Fun Schoool dan TK Rumah Citta merencanakan program kegiatan sekolah meliputi renstra dan renstrop dengan melibatkan guru dan karyawan. Mengorganisasikan personil sekolah agar mereka dapat bekerja sesuai dengan potensi masing-masing. Menggerakkan personel dengan memberikan bimbingan, pengarahan secara intensif dalam jangka waktu tertentu agar mereka dapat bekerja baik dan sesuai dengan tujuan, dan mengawasi kinerja bawahannya dan membimbing agar kinerja bawahan dan kegiatankegiatan sekolah dapat dilaksanakan dengan baik sesuai dengan tujuan sekolah.
\end{abstract}

Kata kunci: penerapan, fungsi manajerial

\section{THE IMPLEMENTATION OF THE MANAGERIAL ROLES OF THE PRINCIPALS OF FASTRACK FUN SCHOOL AND RUMAH CITTA KINDERGARDEN}

\begin{abstract}
The aim of this research is to reveal the implementation of the managerial roles of the principals of Fastrack Fun School and Rumah Citta kindergarten in (1) school programs, (2) school potentials, (3) activating school personnel and (4) school personnel work accomplishment. This research used the qualitative approach. The subjects consisted of: the principals, teachers and employees. The data were collected through observations, interview and documents. The data analysis used trianggulation methodology. The result of this research reveals that the principal of Fastrack Fun School and Rumah Citta plan the school program, including the renstra and renstrop involving teachers and employees. The principals organize the staff in which they can work in their field and potentials. The principals activate commanding the employees by advising and directing. The principals evaluate and conduct the employees in order to make them work and achieve the goals.
\end{abstract}

Keywords: applications, managerial functions 


\section{Pendahuluan}

Sekolah merupakan institusi paling terdepan dalam menjalankan proses pendidikan. Pendidikan secara makro pada akhirnya akan bermuara pada sekolah melalui pembelajaran. Kepala sekolah sangat berperan dalam menggerakkan berbagai komponen di sekolah sehingga proses belajar mengajar di sekolah itu berjalan dengan baik. Dalam menjalankan peranya, seorang kepala sekolah tentu saja harus mampu membuat perencanaan yang sistematis, terpadu, berkelanjutan, dan komprehensif. Target utama perencanaan dalam pendidikan adalah tercapainya tujuan pendidikan secara efektif dan efisien dengan mutu pendidikan yang memuaskan para pelanggan atau stakeholder-nya. Perencanaan yang mencakup penegasan dan kejelasan visi, misi, tujuan, dan strategi organisasi, merupakan hal penting untuk dicermati oleh semua pihak yang berkepentingan terhadap pendidikan, agar organisasi secara ajeg dapat memperoleh keberhasilan dan kesuksesan (Budi Suhardiman, 2012: 13). Kepala sekolah adalah manajer dalam lembaga pendidikan, maka kepala sekolah bertugas untuk mengatur dan mengelola potensi-potensi yang ada (guru, karyawan sekolah, sarana dan prasarana) agar dapat berfungsi secara optimal. Menurut Wahyudi (2009: 68), “Keterampilan manajerial adalah kemampuan seseorang dalam mengelola sumberdaya organisasi berdasakan kompetensi yang ditetapkan dalam rangka mencapai tujuan yang telah ditentukan". Keterampilan manajerial diperlukan oleh manajer agar dapat melaksanakan tugas manajerialnya secara efektif.

TK Fastrack Fun School adalah sebuah taman kanak-kanak (TK) yang baru, namun mempunyai daya tarik bagi para orang tua untuk menyekolahkan anaknya. Keberhasilan tersebut dipengaruhi oleh berbagai faktor, salah satu diantaranya adalah kepala sekolah dalam menjalankan peran dan fungsinya sebagai manajer. TK Fastrack Fun School adalah satu dari dua ratus TK swasta yang ada di Yogyakarta yang berada di Kabupaten Sleman yang berdiri sejak tahun 2010. Sekolah ini terletak di Jl. Perumnas Mundusaren Caturtunggal Depok Sleman, Yogyakarta. Meskipun TK Fastrack Fun School merupakan sebuah taman kanak-kanak yang baru atau tergolong masih relatif muda apabila dibandingkan dengan taman kanak-kanak yang lainnya, namun sekolah ini mengalami perkembangan dan kemajuan yang cukup pesat baik ditinjau dari segi sarana prasarana dan jumlah siswa yang terus meningkat.

Sedangkan TK Rumah Citta adalah sebuah taman kanak-kanak yang berdiri pada tahun 2003 dibawah naungan lembaga swadaya masyarakat Early Childhood Care and Development Resource Center (ECCD-RC) yang bertempat di Jl. D.I. Panjaitan No. 70, Yogyakarta. Sebuah sekolah taman kanak-kanak yang menghargai nilainilai inklusivitas terutama hak-hak anak, keadilan gender, ramah lingkungan hidup, dan kearifan lokal sehingga tumbuh dan berkembang optimal. Rumah Citta menerima anak dengan berbagai latar belakang budaya, sosial, ras dan kemampuan. Semua tergabung dalam kelas yang sama. Anak dengan kebutuhan khusus juga tergabung dengan anak lain, dan dibuatkan program sesuai dengn kebutuhannya. Keberhasilan Rumah Citta dengan 2 kelas diawal tahun berdirinya dengan jumlah anak kurang lebih 10 orang menjadi 5 kelas sampai saaat ini dengan jumlah anak mencapai 80 orang. Berdasarkan kajian di atas, terdapat beberapa alasan yang mendorong untuk melakukan penelitian ini. Pertama, pendidikan TK adalah sebuah pendidikan penting yang menjadi pondasi dan landasan untuk jenjang pendidikan dasar, diharapkan dengan kuatnya pondasi pendidikan usia dini maka pendidikan dasar akan mempunyai dasar yang kuat, sehingga anak didik dapat mengembangkan dan mempunyai karakter sesuai dengan yang diharapkan dalam dunia pendidikan. Kedua, kemajuan dibidang pendidikan membutuhkan administrator pendidikan yang mampu mengelola institusi atau lembaga pendidikan dan mampu meningkatkan kinerja guru dalam mencapai tujuan pen- 
didikan. Ketiga, kajian empiris dengan tema ini menarik untuk dilakukan mengingat perkembangan ilmu dan teori manajemen, khususnya manajemen pendidikan, yang selalu berkembang mengikuti perkembangan jaman.

Berdasarkan latar belakang masalah di atas masalah yang muncul dalam dalam penelitian ini dapat diidentifikasikan sebagai berikut: Belum diperoleh data bagaimana kepala sekolah melaksanakan peran dan fungsi sebagai manajer, peran perencanaan, pengorganisasian, penggerakan, dan evaluasi. Penelitian ini difokuskan kepada penerapan fungsi manajerial Kepala Sekolah Taman Kanak-kanak pada perencanaan, pengorganisasian, penggerakan dan pengawasan di TK Fastrack Fun School dan TK Rumah Citta.

\section{Metode Penelitian}

Jenis penelitian yang digunakan adalah deskriptif kualitatif, dengan harapan dapat menghasilkan gambaran yang luas dan mendalam tentang bagaimana kepala sekolah dengan keterampilan manajerial dan hubungannya dengan kinerja guru.

Data yang diperoleh dalam penelitian ini adalah data kualitatif, yakni data yang berbentuk kata-kata atau kalimat, skema atau bagan, gambar, bukan berbentuk angka-angka dan bukan untuk menguji hipotesis (Sugiyono, 2003: 14).

Penelitian ini dilaksanakan di TK Fastrack Fun School yang terletak di Jl. Seturan Jogjakarta dengan beberapa pertimbangan sebagai berikut: TK Fastrack Fun School adalah sebuah TK yang berkembang dengan menggunakan sistem pengajaran yang berdasarkan kepada sistem letterland. TK Fastrack Fun School tersebut dapat menarik perhatian para orang tua untuk menyekolahkan anaknya di TK tersebut dengan dibuktikan panjangnya waiting list anak yang akan masuk sekolah tersebut. Jumlah Guru dan personil yang selalu berkembang dan mempunyai turn over yang sangat lambat, atau tidak banyak pergantian guru dan personil yang terjadi.
Tempat penelitian yang kedua adalah TK Rumah Citta, yang terletak di Jl. DI. Panjaitan No 70 dengan beberapa pertimbangan: TK Rumah Citta adalah sebuah TK yang mengedepankan proses pendidikan yang berdasarkan dengan usia perkembangan anak. Dual language (bahasa ibu) yang digunakan oleh guru dalam menyampaikan kegiatan belajar mengajar menuntut kualitas guru yang selalu terjaga. Hubungan yang intens antara guru dan orang tua murid, baik dalam bentuk report ataupun komunikasi langsung menjadi salah satu tehnik dalam proses pembelajaran. Subjek penelitian yang dimaksud adalah nara sumber atau informan sebagai sumber diperolehnya data yang diperlukan serta dipandang mengetahui tentang pelaksanaan keterampilan manajerial kepala sekolah di TK Fastrack Fun School dan TK Rumah Citta. Nara sumber yang dimaksud adalah: kepala Sekolah, Guru TK Fastrack Fun School dan TK Rumah Citta, karyawan TK Fastrack Fun School dan TK Rumah Citta, ketua Komite TK Fastrack Fun School dan TK Rumah Citta.

Teknik pengumpulan data dalam penelitian ini menggunakan cara wawancara, observasi dan dokumentasi. Teknik wawancara digunakan untuk mencari informasi tentang hubungan antara penerapan keterampilan kepala sekolah dengan kinerja guru. Observasi dilakukan untuk mencari data pelengkap tentang hubungan antara penerapan keterampilan kepala sekolah dengan kinerja guru. Teknik dokumentasi dilakukan dengan menghimpun dan menganalisis dokumen-dokumen, baik tertulis, gambar maupun elektronik. Penyusunan pedoman wawancara, observasi dan dokumentasi penelitian dimulai dengan identifikasi keterampilan manajerial kepala sekolah, kompetensi guru dan diakhiri dengan pencarian hubungan diantara keduanya. Cara yang digunakan dalam menguji keabsahan data adalah dengan trianggulasi data, yakni triangulasi antara data, metode dan sumber. Trianggulasi metode yang digunakan adalah metode observasi/pengamatan, wawancara dan dokumen. Trianggulasi sumber dilakukan 
untuk menarik kebenaran dari data yang diperoleh, Temuan yang didapat dari hasil wawancara akan diuji dengan cara pengamatan dilapangan dan didukung dengan data dokumentasi. Teknik analisis data yang digunakan adalah Analysis Interactive Model dari Miles dan Huberman (1984: 23), sebuah teknik yang membagi analisis menjadi pengumpulan data, reduksi data, penyajian data, penarikan kesimpulan dan verifikasi data. Dalam penelitian ini, pengumpulan data dilakukan dengan wawancara, observasi dan melihat dokumentasi yang ada untuk melengkapi. Data-data tersebut dicatat dalam bentuk deskriptif tentang apa yang dilihat, didengar, dialami dan dirasakan oleh peneliti. Data ini kemudian disebut transkrip, yang merupakan data alami dan tanpa adanya pendapat atau komentar dari peneliti tentang fenomena yang ditemui. Tahap ini merupakan tahap pemilihan, pemusatan perhatian, penyederhanaan, pengabstrakan dan transformasi data asli atau data kasar yang didapatkan dari catatan dilapangan. Tahap selanjutnya adalah memilah dan memilih data yang sesuai dengan permasalahan penelitian dan kemudian disederhanakan dan disimpan dalam catatan tersendiri, data yang tidak berhubungan atau tidak berguna akan dibuang, agar tidak menggangu penelitian. Proses ini dilakukan berulang kali agar terhindar dari makna ganda.

Menyajikan data adalah menyajikan temuan yang sudah dipilah dan dipilih agar menjadi sebuah susunan yang sistematis dan menjadi satu kesatuan yang utuh. Penyajian data merupakan tahap untuk memahami apa yang sedang terjadi, apa yang harus dilakuakn agar dapat dianalisis dan dapat digunakan dalam pengambilan langkah selanjutnya. Proses penarikan kesimpulan dilakukan berdasar fenomena dan pola-pola yang saling berhubungan, dan apabila dalam kesimpulannya penulis belum menemukan hubungan antara fenomena-fenomena yang akan disimpulkan, maka kembali ke lapangan dan mengadakan kralifikasi melalui verifikasi data akan dilakukan oleh peneliti.
Tahap-tahap yang akan dilalui dalam sebuah analisi data adalah: pengumpulan data melalui observasi, wawancara maupun studi dokumentasi. Melakukan pemisahan data dari hasil observasi, wawancara dan studi dokumentasi. Mendeskripsikan data yang sudah dipilih dan dipilah kedalam penyajian data. Membuat analisis akhir, yakni mencari hubungan atau pola yang muncul dari temuan dilapangan dengan apa yang seharusnya atau idealnya ada berdasar dengan pedoman standar pelayanan yang dikeluarkan oleh Depdiknas.

\section{Hasil Penelitian dan Pembahasan}

Pada bab ini akan disajikan hasil penelitian dan pembahasan hasil penelitian. Bab ini akan terbagi menjadi tiga (3) bagian, bagian (A) gambaran umum subjek penelitian, pada bagian (B) deskripsi hasil penelitian, dan pada bagian (C) akan disajikan pembahasan hasil penelitian. Pada gambaran umum akan disajikan data siswa, kepegawaian, sarana prasarana dan keuangan sekolah. Pada bagian hasil penelitian akan disajikan secara menyeluruh tentang hasil temuan penelitian penerapan fungsi manajerial kepala sekolah yang terdiri dari: (1) uraian tentang perencanaan sekolah; (2) pengorganisasian sekolah; (3) penggerakan sekolah; dan (4) uraian tentang pengawasan sekolah. Aspek-aspek yang disajikan dalam tabel adalah pengembangan dari instrument pemetaan kompetensi kepala sekolah yang dibuat oleh Lembaga Penelitian dan Pengembangan Kepala Sekolah (LP2KS). Untuk kinerja Guru hasil penelitian akan disajikan secara menyeluruh mengenai kinerja guru yang terdiri dari: (1) kompetensi paedagogik, (2) kompetensi pribadi, (3) kompetensi sosial, dan (4) kompetensi profesional.

\section{TK. Fastrack Yogyakarta}

Tujuan dari berdirinya Taman Kanan-kanak Fastrack Fun School adalah untuk memenuhi kebutuhan masyarakat akan lembaga pendidikan pra sekolah yang bisa mempersiapkan siswanya untuk ber- 
siap akan adanya globalisasi. Taman Kanak-kanak Fastrack Fun School bertempat di Seturan, yakni di Jl. Perumnas Mundusaren Caturtunggal Depok Sleman, Yogyakarta. Jumlah Guru Taman Kanakkanak Fastrack Fun School adalah 24 Guru yang mengajar dari Daycare sampai dengan TK Besar dengan kelas Universal dan Nusantara. Untuk jumlah tenaga staff terdapat 13 yang terdiri dari Direktur utama sampai dengan satpam. Taman Kanak-kanak Fastrack Fun School yang berlokasi di Jl. Perumnas Mundusaren Caturtunggal Depok Sleman Yogyakarta memiliki 8 ruangan yang terdiri dari 3 ruang kelas, 1 ruang tunggu, 1 ruang kantor, 4 kamar mandi, dan 1 dapur. Sarana dan prasarana belajar terdiri dari dalam dan luar kelas yang cukup beragam dan mendukung proses belajar mengajar dalam rangka memenuhi kebutuhan siswa. Taman Kanak-kanak Fastrack Fun School merupakan sekolah swasta atau sekolah yang dimiliki oleh yayasan, sehingga keuangan sekolah yang terdiri dari biaya operasional sekolah maupun biaya operasional pendidikan ditanggung oleh orang tua siswa dan dibantu dengan yayasan. Pengelolaan keuangan Taman Kanakkanak Fastrack Fun School mengacu kepada ketentuan pemerintah sesuai dengan yang berlaku dalam sekolah swasta pada umumnya. Yayasan memegang peranan penting dalam proses pengelolaan keuangan di Taman Kanak-kanak Fastrack Fun School.

\section{TK. Rumah Citta}

Rumah Citta merupakan salah satu divisi dari Lembaga Swadaya Masyarakat Early Childhood Care and Development Resource Center (ECCD-RC) Jogja. Lembaga ini bertempat di Jl. D.I. Panjaitan 70, Yogyakarta. Rumah Citta berdiri tahun 2003. Awal berdiri terdiri dari 2 kelas, yaitu 1 kelas Kelompok Bermain (KB) dan dan 1 kelas Taman Kanak-kanak (TK). Jumlah anak \pm 10 orang. Tahun 2004 Rumah Citta membuka TPA. Sampai saat ini, ada 5 kelas yang terdiri dari 2 kelas KB, 1 kelas TPA, 1 kelas TK Kecil dan 1 kelas TK Besar. Jumlah anak \pm 80 orang. Jumlah Guru Taman Kanak-kanak Rumah Citta adalah 15 Guru yang mengajar dari Daycare sampai dengan TK Besar. Untuk jumlah tenaga staf terdapat 4 yang terdiri dari Direktur Utama sampai dengan satpam. Taman Kanak-kanak Rumah Citta memiliki 94 siswa yang terdiri dari 26 anak play group dan 68 anak untuk TK. TK Rumah Citta yang terletak di Jl. DI Panjaitan 70 Yogyakarta memiliki ruangan yang terdiri dari 5 kelas yang terdiri dari 2 kelas KB, 1 kelas TPA, 1 kelas TK Kecil dan 1 kelas TK Besar. Jumlah anak \pm 80 orang. Sarana dan prasarana belajar terdiri dari dalam dan luar kelas yang cukup beragam dan mendukung proses belajar mengajar dalam rangka memenuhi kebutuhan siswa. TK Rumah Citta merupakan sekolah yang berada dibawah Lembaga Swadaya Masyarakat Early Childhood Care and Development Resource Center (ECCD-RC), sehingga keuangan sekolah yang terdiri dari biaya operasional sekolah maupun biaya operasional pendidikan ditanggung oleh orang tua siswa dan dibantu oleh lembaga. Pengelolaan keuangan TK Rumah Citta mengacu kepada ketentuan pemerintah sesuai dengan yang berlaku dalam sekolah swasta pada umumnya. Lembaga memegang peranan penting dalam proses pengelolaan keuangan di TK Rumah Citta.

Deskripsi hasil penelitian ini untuk mengetahui keterampilan manajerial kepala sekolah Taman Kanak-kanak dan hubungannya dengan kinerja guru akan terdapat empat (4) bagian, yakni: (1) perencanaan; (2) pengorganisasian; (3) penggerakan; dan (4) pengawasan, Bagian keterampilam manajerial sekolah (1) perencanaan, perolehan data berasal dari teknik wawancara dan dokumentasi, dengan fokus yang diarahkan kepada (a) penyusunan program sekolah dan pengembangannya (renstra dan renstrop). Bagian (2) pengorganisasian, deskripsi diperoleh dari wawancara dan dokumentasi dengan fokus (a) pengembangan organisasi sekolah, (b) pengembangan sumber daya manusia, (c) sarana prasarana, (d) hubungan sekolah 
dengan masyarakat, (e) kesiswaaan, dan (f) keuangan sekolah. Bagian (3) penggerakan, deskripsi diperoleh dengan sistem wawancara dan dokumentasi yang berfokus kepada (a) pemberian bimbingan, (b) pemberian teladan, dan (c) arahan. Bagian (4) pengawasan, deskripsi diperolah dari tehnik wawancara dan dokumentasi dengan fokus proses pengawasan pelaksanaan kegiatan Taman Kanak-kanak.

Keterampilan Manajerial Sekolah TK. Fastrack Fun School

Proses penyusunan pengembangan sekolah meliputi proses penyusunan rencana strategis (renstra), rencana operasional (renstrop), rencana tahunan, dan rencana anggaran belanja sekolah (RAPBS). Untuk sumber data dapat dilihat dalam proses wawancara dan dokumentasi. Pertanyaan tentang penyusunan rencana pengembangan sekolah diajukan kepada kepala Taman Kanak-kanak dan beberapa guru, "Apakah penyusunan rencana pengembangan sekolah dilakukan awal tahun dan dalam waktu tertentu?" Kepala sekolah dan beberapa guru yang diwawancarai memberikan jawaban yang sama, bahwa "Setiap akhir semester terdapat pertemuan yang akan membahas tentang rencana pengembangan sekolah yang nantinya akan menjadi pegangan bersama selama satu (1) semester kedepan, dan nantinya akan ada pertemuan dalam satu (1) semester sebanyak dua (2) kali untuk menerima masukan dari level yang paling bawah sehingga nantinya dapat digunakan untuk menentukan kebijakan selanjutnya seperti apa. "Hal ini juga menjawab tentang prinsip transparansi dan akuntabilitas dan melibatkan setiap warga sekolah. "Dari feedback teman-teman nanti kita bawa ke manajemen, kita punya agenda rutin ketemu dengan manajamen (para manajer)." Penyusunan proposal kegiatan merupakan sebuah kegiatan yang dilakukan dalam lembaga pendidikan. Ketika hal tersebut ditanyakan kepada Kepala Taman Kanak-kanak, Miss Dita mengatakan "Dalam satu (1) semester pasti kita buat proposal, tidak pernah ditengah-tengah semester. Perencanaan pasti berada di awal semester supaya bisa berjalan sesuai dengan proposalnya." Dari hasil wawancara dengan para guru, mereka juga terbiasa untuk membuat program disetiap akhir semester (setelah prosesi terima raport) untuk membuat proposal untuk satu (1) semester kedepan, dan mereka memahami pentingnya pembuatan proposal. "Kita sudah bicarakan bersama-sama, untuk sharing dan mempersiapkan kedepannya. Untuk mempersiapkan sylabus dan sebagainya." Dari kesimpulan diatas, proses pembuatan proposal kegiatan sudah menjadi sebuah keharusan bagi kepala Taman Kanak-kanak dan guru dalam setiap awal semester, agar semester yang dimaksud dapat berjalan sesuai dengan rencana dan lancar sesuai dengan rencana. Secara rinci kompetensi Kepala Taman Kanak-kanak terkait penyusunan

Pengorganisasian yang dilaksanakan di dalam sekolah adalah menyusun dan membentuk gugus kerja antara personil sekolah serta hubungan di antaranya agar dapat terbentuk suatu pola kerja demi tercapainya tujuan pendidikan. Berdasarkan wawancara, Kepala Taman Kanakkanak menyatakan "Untuk struktur organisasi di Fastrack Fun School agak berbeda dengan Taman Kanak-kanak yang lain, untuk kepala sekolah akan dibantu dengan wakil kepala sekolah dengan tugas yang lebih ke dalam, yakni berhubungan dengan guru secara harian dan kepala sekolah akan berurusan dengan pihak luar dan mengontrol wakil kepala sekolah". Dari hasil pengamatan peneliti dengan hadir beberapa kali di Taman Kanak-kanak dan wawancara dapat disimpulkan jika pengorganisasian telah berjalan dengan baik.

Hasil wawancara dengan kepala Taman Kanak-kanak menunjukkan bahwa sekolah mempunyai perencaan yang matang terhadap kebutuhan guru dan staf. "Untuk penambahan guru akan langsung dengan uncle Dhodok, semisal ada kebutuhan guru, saya akan meminta ke atas". Untuk pengelolaan sumber daya guru dilakukan secara rutin di akhir semester. 
"Training besar ada diakhir semester dimana anak-anak libur dan guru tetap masuk. Disitu akan ada pengembangan ke profesionalitasan dari guru maupun kegiat-an nonguru. Jadi pasti setiap guru di akhir semester ada training. Dari security juga, kita berikan pelatihan satpam, ada juga training-training lain semisal, kita kirim ke PAUD."

Berdasarkan pengamatan, sarana dan prasarana Taman Kanak-kanak Fastrack Fun School telah memiliki persyaratan sebagai sebuah Taman Kanakkanak, yakni memiliki sarana permainan edukatif baik di dalam ruangan maupun diluar ruangan. Hasil wawancara dengan Kepala Taman Kanak-kanak, untuk sarana dan prasarana mereka berupaya sebaik mungkin untuk bisa memaksiamalkan. “Untuk maintenace diajukan oleh guru kepada saya, nanti saya ajukan ke miss Dina, lalu miss Dina mengajukan ke direktur eksekutif." Kesimpulan dari hasil wawancara dan dokumentasi yaitu adanya perencanaan untuk perawatan jangka pendek dan jangka panjang serta alur koordinasi yang jelas, sehingga sarana dan prasarana yang sudah ada dapat terjaga dan terpenuhi dengan baik.

Hubungan masyarakat dengan sekolah adalah sebuah bentuk pemberdayaan masyarakat untuk memperoleh dukungan, nama baik, dan sosialisasi program sekolah. Hasil wawancara dengan Kepala Taman Kanak-kanak diperoleh informasi bahwa mereka mempunyai program rutin untuk bertemu dengan warga sekitar dan orangtua. "Kita harus menjaga baik hubungan dengan warga disini, paling gampang adalah kita harus ikut iuran kampung dan mengikuti tatacara kampung sini, dan tetap berpartisipasi." Kegiatan yang lebih fokus terhadap orang tua dilakukan oleh setiap guru dengan memberikan waktu untuk berbicara terhadap orangtua dalam setiap harinya, sehingga perkembangan anaknya dalam setiap harinya dapat diketahui oleh orangtua. Upaya membuka kelas trial kepada masyarakat umum merupakan strategi yang dilakukan oleh Taman Kanak-kanak Fastrack Fun
School untuk berkomunikasi dengan masyarakat umum. Kesimpulanya adalah telah terdapat upaya kreatif dalam mengembangkan dan membuat hubungan dengan masyarakat.

Salah satu elemen penting dalam manajemen pendidikan adalah kesiswaan. Hasil dari wawancara dengan kepala Taman Kanak-kanak dan beberapa guru menunjukkan jika mereka sudah mempunyai perencaan yang matang dalam penerimaan siswa dan tahap-tahap selanjutnya, sehingga semua rangkaian kegiatan belajar mengajar dapat berjalan dengan lancar."Semisal kita pengen mempunyai kelas baru lagi, lalu kita jadikan target, langsung kita implementasikan dan informasikan teman-teman marketing supaya fokus untuk telepon, dan membuat kelas trial".

Keuangan sekolah adalah salah satu elemen penting dalam mewujudkan pendidikan yang baik dan layak di Taman Kanak-kanak. Dana yang memadai menentukan banyaknya program dan kegiatan yang dapat dilakukan. Secara umum manajemen keuangan Taman Kanak-kanak telah berjalan dengan baik, pengelolaan dan pencarian dana sudah terencana dengan baik. "Untuk menjalankan sekolah ini pure berdasar uang dari para orang tua siswa, dan itu cukup."

Penggerakan adalah sebuah langkah dimana seorang manajer memberikan bimbingan, dorongan, semangat, dana memberikan berbagai usaha untuk kinerja yang optimal agar tujuan yang sudah ditentukan dapat tercapai. Dari hasil wawancara dengan kepala sekolah dan beberapa guru didapati bahwa proses penggerakan sudah berlangsung dengan baik di Taman Kanak-kanak Fastrack Fun School. "Ya kita pernah outbound bareng, pernah diinepin di resort bareng, buka puasa bareng, karaoke, dan bahkan kita punya arisan juga."

Pengawasan secara umum terdiri dari empat langkah, yaitu: (1) menetapkan suatu kriteria atau standar, (2) mengukur nilai kinerja, (3) membandingkan kinerja dengan standar yang ditetapkan, dan (4) memperbaiki penyimpangan dari standar 
dengan tindakan pembenaran. Berdasarkan hasil wawancara dengan kepala Taman Kanak-kanak menunjukkan bahwa program pengawasan sudah dapat berjalan dengan baik, dan sudah menjadi kebiasaan di Taman Kanak-kanak Fastrack Fun School. "Dalam satu (1) semester kita punya evaluasi yang terencana, paling tidak satu (1) semester sekali". Berdasarakan hasil observasi, diketahui bahwa proses pengawasan yang dilakukan di Taman Kanak-kanak Fastrack Fun School sudah berjalan dengan baik. Mulai dari perencanaan sampai dengan pelaksanaan di lapangan dilakukan pengawasan yang cukup ketat baik oleh kepala Taman Kanak-kanak, wakil Taman Kanak-kanak, maupun direktur program. Wawancara yang dilakukan dengan beberapa guru menunjukkan bahwa mereka bisa mendapatkan pembinaan secara langsung, ditambah dengan pengawasan yang ketat dari kepala Taman Kanak-kanak dan wakil kepala Taman Kanak-kanak. Para guru juga berpendapat bahwa program pembinaan yang dilakukan sudah cukup bervariasi, semisal dengan outbound untuk meningkatkan kebersamaan dan motivasi guru. Untuk pembinaan proses mengajar di kelas dilakukan dengan mengundang trainer letterland dan mengajak para guru untuk roleplay, pengiriman guru untuk seminar pendidikan anak usia dini (PAUD) dan mempresentasikan apa yang didapat di depan rekan guru yang lain.

Keterampilan Manajerial Sekolah TK. Rumah Citta

Proses penyusunan pengembangan sekolah meliputi proses penyusunan rencana strategis (renstra), rencana operasional (renstrop), rencana tahunan, dan rencana anggaran belanja sekolah (RAPBS). Untuk sumber data dapat dilihat dalam proses wawancara dan dokumentasi. Pertanyaan tentang penyusunan rencana pengembangan sekolah diajukan kepada kepala sekolah dan beberapa guru "Apakah penyusunan rencana pengembangan sekolah dilakukan awal tahun ada dalam waktu tertentu?" Kepala sekolah menjawab "Setiap tahun, dibulan Juli selesai rapotan, kami para guru akan belajar bersama mengolah kembali kurikulum, apakah masih layak untuk tahun depan. Selama satu (1) hari untuk rencana strategis dan rencana operasional, begitu juga dengan RAPBS, selama satu (1) tahun juga." Ketika ditanyakan "Apakah dalam penyusunan rencana pengembangan sekolah memegang teguh prinsip-prinsip penyusunan rencana, yakni akuntabilitas, transparansi dan melibatkan partisipasi setiap warga sekolah?" Kepala Taman Kanak-kanak mengiyakan, dan jawaban yang sama juga didapat dari wawancara dengan beberapa Guru.

Penyusunan proposal kegiatan merupakan sebuah kegiatan yang dilakaukan dalam lembaga pendidikan dilaksanakan. Ketika hal tersebut ditanyakan kepada Kepala Taman Kanak-kanak, Bu Indri mengatakan "Dalam satu (1) tahun pasti kita buat proposal berdasar RAPBS, namun ditengah-tengah pelaksanaan dimungkinkan adanya perubahan, rencana sih ada, namun biasanya action-nya setelah Juli. Paling kalo udah dapet targetnya baru diadakan pendekatan. Aku balik lagi dengan sistem kerjaku, jadi apapun yang dilakukan untuk tahun depan akan aku pikirkan tahun depan." Berdasarkan temuan diatas dapat disimpulkan bahwa penyusunan proposal kegiatan tetap dibuat disetiap akhir tahun ajaran, namun tetap bisa mengalami perubahan di tengah pelaksanaan yang berkaitan dengan kondisi pada saat itu.

Pengorganisasian yang dilaksanakan di dalam sekolah adalah menyusun dan membentuk gugus kerja antara personel sekolah serta hubungan diantaranya agar dapat terbentuk suatu pola kerja agar tercapainya tujuan pendidikan. Berdasarkan pengamatan disekolah diketahui jika, Kepala Taman Kanak-kanak sadar pentingnya pengorganisasian, semakin baik pula lembaganya. Hal senada disampaikan juga oleh guru bahwa pengorganisasian sangat diperlukan dalam setiap kegiatan dengan tujuan: membagi-bagi kegiatan atas bagian-bagian yang khusus; mempermudah 
pengawasan oleh pihak atasan; mempermudah pelaksanaan kerja; mencegah terjadinya bertumpuknya pekerjaan dan overlapping;penempatan tenaga sumber daya manusia yang tepat dengan bidang pekerjaan yang ada. Berdasar hasil pengamatan dan wawancara di sekolah dapat disimpulkan bahwa pengorganisasian telah berjalan dengan baik,

Hasil wawancara dengan kepala

Taman Kanak-kanak menunjukkan bahwa sekolah mempunyai perencanaan yang matang terhadap kebutuhan guru dan staf. "Untuk komposisinya tergantung rasio anak, playgroup 1:5, playgroup kecil 1:2,5, TK kecil 1:7, tk besar 1:10, dan pra sd 1:10. Dari sekolah setelah pelatihan dasar, setelah tiga (3) bulan di kelas, nanti ada pelatihan besar yang seluruh staf baru akan denganku, tapi untuk guru akan ada yang rutin kecil-kecil, ada refreshment setiap hari senin, di labschool." Hasil dari wawancara dan pengamatan menggambarkan bahwa Kepala Taman Kanak-kanak mengetahui benar pentingnya pembagian tugas dalam lembaganya.

Berdasarkan pengamatan, sarana dan prasarana TK Rumah Citta telah memiliki persyaratan sebagai sebuah TK, yakni memiliki sarana permainan edukatif baik didalam ruangan maupun di luar ruangan. Hasil wawancara dengan guru dan kepala Taman Kanak-kanak, untuk sarana dan prasarana mereka berupaya sebaik mungkin untuk bisa memaksimalkan peralatan yang ada, bahkan mereka menggunakan limbah untuk menjadi sarana prasarana. "Kami semaksimal mungkin memanfaatkan bahan limbah untuk memuat maianan anak-anak. Kami lebih percaya mainan yang dibuat oleh anakanak akan lebih bermakna oleh mereka."

Hubungan masyarakat dengan sekolah adalah sebuah bentuk pemberdayaan masyarakat untuk memeproleh dukungan, nama baik, dan sosialisasi program sekolah. Hasil wawancara dengan Kepala Taman Kanak-kanak diperoleh informasi bahwa mereka mempunyai program rutin untuk bertemu dengan orang tua. "Sebenernya ini untuk teman- teman media kampanye di lembaga, kami sering membuat workshop untuk warga sekitar, kami juga mengadakan hubungan dengan masyarakat, pak lurah, pak camat, kampung dan sebagainya, tapi untuk feedback positif dari mereka belom ada. Orangorang di sekitar sini merasa sekolah ini eksklusif, dan mereka jarang mengakses ke sini, padahal kami terbuka buat mereka."

Salah satu elemen terpenting dalam manajemen pendidikan adalah kesiswaan. Hasil dari wawancara dengan kepala Taman Kanak-kanak dan beberapa guru menunjukkan jika mereka sudah mempunyai perencanaan yang matang dalam penerimaan siswa dan tahap-tahap selanjutnya, sehingga semua rangkaian kegiatan belajar mengajar dapat berjalan dengan lancar."Untuk anak berkebutuhan kusus, karena kami sekolah inklusi, proses awalnya adalah menyerahkan hasil diagnosa, ini penting untuk kami untuk tau kebutuhan anak tersebut apa, sehingga teknik dampingannya akan seperti apa. Untuk anak yang lain, saya atau admin akan menjelaskan kegiatannya apa saja, akan banyak kedatangan tamu, dan sebagainya."

Keuangan sekolah adalah salah satu elemen penting dalam mewujudakan pendidikan yang baik dan layak di Taman Kanak kanak. Dana yang memadai menentukan banyaknya program dan kegiatan yang dapat dilakukan. Secara umum manajemen keuangan Taman Kanak-kanak telah berjalan dengan baik, pengelolaan dan pencarian dana sudah terencana dengan baik. "Karena kami sekolah inklusi, aku punya cara sendiri dalam mengelola keuangan, aku berdasarkan pengeluaran lalu dihitung untung pendapatannya. Ada bantuan dari dinas, juga donatur. Lainya kami terbuka dengan orangtua murid mengenai pengeluaran kami, dikelas selalu ada satu (1) murid yang kami bantu untuk permasalahan ekonominya, apakah ada orang tua yang mau menambah SPP-nya, karena basic ekonomi orangtua murid kami beragam, ada yang anggota dewan, pengusaha dan orang biasa".

Penggerakan adalah sebuah langkah dimana seorang manajer memberikan 
bimbingan, dorongan, semangat, dana memberikan berbagai usaha untuk kinerja yang optimal agar tujuan yang sudah ditentukan dapat tercapai. Dari hasil wawancara dengan kepala sekolah dan beberapa guru didapati bahwa proses penggerakan sudah berlangsung dengan baik di TK Rumah Citta. "Diluar gaji aku sebut itu kesejahteraan, itu berupa gathering satu (1) bulan sekali, kami juga punya jalan-jalan yang sambil belajar, yang itu biasanya 3 bulan sekali. Aku juga punya uang program untuk labschool yang biasanya untuk hal-hal kecil, ntah pulsa, vitamin, jus, coklat atau eskrim. Mungkin kecil, tapi berarti, kalo gak ada jugaditanya-tanya."

Pengawasan secara umum terdiri dari empat langkah, yaitu: (1) menetapkan suatu kriteria atau standar, (2) mengukur nilai kinerja, (3) membandingkan kinerja dengan standar yang ditetapkan, dan (4) memperbaiki penyimpangan dari standar dengan tindakan pembetulan. Berdasarkan hasil wawancara dengan kepala Taman Kanak-kanak menjunjukkan bahwa program pengawasan sudah dapat berjalan dengan baik, dan sudah menjadi kebiasaan di TK Rumah Citta meskipun beragam bentuknya. "Untuk yang berkaitan dengan personal, aku lebih senang dengan cara informal, sehingga mereka tidak merasa tertekan, bentuknya kadang aku kasih surat kecil, biasanya berkaitan dengan teknik pendampingan, ada yang salah dan itu harus diubah. Biasanya aku minta off untuk khusus melihat kelas dari jam 8 sampai jam 12, itu artinya aku tidak bisa diganggu."

Berdasarkan hasil observasi, diketahui bahwa proses pengawasan yang dilakukan di Taman Kanak-kanak Rumah Citta sudah berjalan dengan baik. Mulai dari perencanaan sampai dengan eksekusi di lapangan dilakukan pengawasan yang cukup ketat oleh kepala sekolah. Wawancara yang dilakukan dengan beberapa guru menunjukkan bahwa mereka bisa mendapatkan pembinaan secara langsung, ditambah dengan pengawasan yang ketat dari kepala Taman Kanak-kanak.Para guru juga berpendapat bahwa program pem- binaan yang dilakukan sudah cukup bervariasi, semisal dengan labschool, ajang pertemuan rutin mereka setiap hari senin, pertemuan yang dilakukan secara informal tapi berisi untuk meningkatkan kebersamaan dan motivasi guru.

Penyusunan rencana pengembangan sekolah yang meliputi penyusunan rencana strategis (renstra), dan rencana operasional (renstrop), rencana tahunan, dan rencana anggaran belanja sekolah (RAPBS) merupakan bagian penting di dalam sekolah, sehingga perlu dilakukan dengan seksama dan melibatkan penghuni sekolah, karena merupakan acuan untuk sebuah proses perkembangan yang berkelanjutan.

Kepala Taman Kanak-kanak dan beberapa Guru yang diwawancarai memberikan pendapat yang sama, yakni dibuat setiap awal tahun ajaran baru dan nanti akan ada peninjauan dan atau penambahan di tengah antara semester, sesuai dengan perkembangan dan kebutuhan. Pihak sekolah menuliskan berdasar sekala prioritas dan akan melaksanakanya selama satu tahun kedepan. Berdasar penelitian tersebut diatas dapat diketahui jika proses perencanaan dilakukan di awal tahun dan sebagaimana mungkin Kepala Taman Kanak-kanak dan guru akan melaksanakan rencana tersebut.

Dikarenakan kedua Taman Kanakkanak ini berdiri secara mandiri, meskipun berada dibawah yayasan atau lembaga, Kepala Taman Kanak-Kanak dan Guru berusaha semaksimal mungkin untuk tetap bergerak berdasarkan acuan yang sudah dibuat di awal tahun, dan ketika terdapat perubahan, atau penambahan Kepala Taman Kanak-kanak dan Guru akan membuat catatan tertulis, sehingga akan manjadi catatan mereka di tahun berikutnya. Proposal kegiatan, yang merupakan bagian dari perencanaan menjadi bagian penting yang dipahami oleh Kepala Taman Kanakkanak, dan akan menjadi pegangan selama satu semester, atau bahkan selama satu tahun, namun tetap terdapat penyesuaian berdasarkan keadaan. Sehingga penyusunan proposal kegiatan menjadi bagian 
pokok yang akan dijalankan selama jangka waktu yang disepakati.

Perencanan mempunyai fungsi sebagai pedoman pelaksanaan dan pengendalian, sebagai alat pengembangan quality assurance, menghindari pemborosan sumber daya, dan sebagai alat untuk dapat mencapai accountability sebuah kelembagaan. Yang terpenting dalam sebuah perencanaan adalah terhubungnya kepentingan masa depan dengan kegiatan, proses yang sistematis serta sebuah tujuan tertentu. Agar sebuah lembaga dapat memastikan keberlangsungannya, perencanaan yang baik menjadi sebuah keharusan.

Rencana strategis dan rencana operasional adalah dasar sebuah lembaga pendidikan dalam melangkah. Kedua Taman Kanak-kanak telah mempunyai pelaksanaan pembuatan rencana strategis dan rencana operasional yang baik, meskipun dengan interval yang berbeda, ada yang setiap satu (1) tahun dan ada yang setiap satu (1) semester.

Keefektifan pola pengelolaan di TK Fastrack Fun School dengan TK Rumah Citta mempunyai ciri dan dasar yang sama, karena mereka berada di bawah sebuah yayasan ataupun sebuah lembaga, namun mereka mempunyai kemandirian untuk mengatur dan menata secara organisasi. Perbedaan yang cukup mencolok terjadi di dalam sarana prasarana. TK Fastrack Fun School memiliki sarana dan prasarana yang sangat memadai untuk ukuran sebuah Taman Kanak-kanak, hal ini didukung dengan adanya dukungan dari orangtua murid yang sangat memadai. Untuk pengelolaan sumber daya manusia, kedua Taman Kanak-kanak tersebut mempunyai kelebihan masing-masing dengan pola dan cara mereka sendiri. Cara membangun pola berkomunikasi dengan orang tua murid, penghuni sekolah, dan masyarakat sekitar juga mempunyai prinsip yang sama, meskipun hasil yang diraih setiap Taman Kanak-kanak berbeda.

Penggerakan di sini berarti pemberian bimbingan, dorongan, semangat, dan memberikan berbagai usaha untuk kinerja yang optimal agar tujuan yang sudah ditentukan dapat tercapai. Setiap taman Kanak-kanak mempunyai gaya dan cara yang berbeda, hal ini didasarkan kepada gaya kepemimpinan Kepala Taman Kanak-kanak. Taman Kanak-kanak Rumah Citta memberikan dorongan dan semangat kepada para Guru dengan memberikan mereka stimulan berupa buku yang berkaitan dengan pendidikan, memberikan perhatian berupa dorongan agar para Guru jangan mau berhenti untuk mengembangkan potensi diri. Pemberian sarana outing bersama, karaoke, dan menghabiskan waktu bersama di tempat wisata merupa-kan cara-cara yang digunakan oleh kedua Taman Kanak-kanak dalam rangka memberikan semangat dan refreshment bagi para Guru agar tetap dapat mencapai tujuan pendidikan yang sudah ditetapkan masing-masing Taman Kanak-kanak.

Pengawasan di Taman kanakkanak Fastrack Fun School dan Taman Kanak-kanak Rumah Citta sudah dilakukan sesuai dengan prosedur yang ada dari Dinas Pendidikan. Dalam penelitian ini ada tiga aspek penting yang dilihat, yakni penilaian kinerja, pembinaan dan pemantauan, sedangkan dalam aspek pengawasana secara umum terbagi ke dalam pengawasan akademik dan manajerial. Kedua Kepala Taman Kanak-kanak telah melaksanakan fungsi tersebut, keduanya telah melaksanakan proses pengawasan dari tahap perencanaan, dimana keduanya mempunyai program kerja yang pasti, meskipun mempunyai perbedaan dalam proses pembuatan rencana kerja, yakni dalam satu tahun dan satu semester.

Proses pembinaan secara administratif maupun akademik telah dilakukan di kedua Taman Kanak-kanak. Keduanya mempunyai gaya dan cara masing-masing yang menjadikan karakteristik dari setiap Taman Kanak-kanak. Taman Kanak-kanak Fastrack Fun School mempunyai gaya yang sistematis dan terinci, sedangkan Taman Kanak-kanak mempunyai gaya yang lebih fleksibel dengan gaya kepemimpinan yang semi formal, namun tetap tidak melupakan fungsi dari pembinaan. Dengan proses pengawasan, diharapkan mutu pendidikan 
dapat terjaga secara berkelanjutan, sehingga dapat meningkatkan kinerja dan lembaga pendidikan perlu melakukannya secara terprogram dan berkesinambungan.

\section{Simpulan dan Saran}

Berdasarakan hasil penelitian dan pembahasan dapat disimpulkan bahwa: Kepala Taman Kanak-kanak Fastrack Fun School dan Taman Kanak-kanak Rumah Citta telah menyusun perencanaan sekolah untuk semua tingkatan secara lengkap. Perencanaan yang telah disusun oleh pihak Taman Kanak-kanak meliputi: Rencana strategis (renstra) berupa visi, misi dan tujuan, rencana operasional (renstrop) berupa rencana kerja, rencana tahunan, berupa rencana kegiatan, jadwal, da rencana pendapatan dan penggunaan dana. Penyusunan perencanaan sekolah dalam berbagai tingkat di kedua Taman Kanakkanak melibatkan guru dan lembaga atau yayasan. Kepala Taman Kanak-kanak Fastrack Fun School dan Taman Kanakkanak Rumah Citta dalam melaksanakan fungsi pengorganisasian telah membuat struktur organisasi dan deskripsi tugas. Pendayagunaan sumberdaya manusai di kedua Taman Kanak-kanak Fastrack Fun School dan Taman Kanak-kanak Rumah Citta dilakukan melalui: Pelatihan dan forum kelompok kinerja guru dan karyawan. Pembinaan yang dilakukan secara rutin dengan agenda menyelesaikan kesulitan-kesulitan yang dihadapi guru dan karyawan dalam kegiatan pembelajaran maupun dalam pelaksanaan program sekolah. Pelaksanaan pembinaan di kedua Taman Kanak-Kanak mempunyai kesamaan, yakni dalam setiap minggu dan di setiap awal semester. Pengelolaan siswa yang dilakukan oleh Taman Kanak-kanak Fastrack Fun School dan Taman Kanakkanak Rumah Citta mengikuti kebijakan dari Dinas Pendidikan, yakni: Penerimaan siswa baru dilaksanakan pada setiap awal tahun ajaran baru dan berdasarkan dengan usia. Pengelompokan dan penempatan siswa dilakukan berdasar usia. Pengelolaan sarana dan prasarana yang dilakukan
Taman Kanak-kanak Fastrack Fun School dan Taman Kanak-kanak Rumah Citta berbeda, hal ini dikarenakan belum adanya standar opersional prosedur yang mengatur secara jelas tentang penyimpangan dan pemanfaatan alat. Namun dari sisi administrasi, Taman Kanak-kanak Fastrack Fun School lebih rapi dan tertata. Hubungan sekolah dengan masyarakat dilakukan dengan beberapa cara: Taman Kanak-kanak Fastrack Fun School melalui beberapa media, seperti web, pembukaan kelas trial, pembukaan parenting class, bahkan mengikuti pameran.Hubungan sekolah dengan masyarakat di Taman Kanak-kanak Rumah Citta adalah dengan melakukan hubungan secara langsung, melalui bantuan sebagai nara sumber bagi pertemuan warga sekitar untuk menjelaskan tentang dunia anak dan inklusifitasnya, pameran, dan siaran radio. Pengelolaan keuangan di Taman Kanakkanak Fastrack Fun School dan Taman Kanak-kanak Rumah Citta disusun diawal tahun ajaran baru. Pelaksanaan fungsi pengawasan di Taman Kanak-kanak Fastrack Fun School dan Taman Kanak-kanak Rumah Citta dilakukan oleh pengawas dari lembaga atau organisasi dan Kepala Taman Kanak-kanak. Pengawas secara rutin datang ke Taman Kanak-kanak mininal satu bulan. Pengawasan yang dilakukan oleh kepala Taman Kanak-kanak dilakukan satu minggu sekali. Berdasar temuan penelitian, saran yang dapat diberikan agar Kepala Taman Kanak-kanak menjaga dan meningkatkan komunikasi dan koordinasi dengan seluruh pihak yang terkait dengan sekolah. Serta meningkatkan kemampuan manajerialnya agar Guru dan karyawan dapat mengoptimalkan kinerjanya, sehingga tujuan pendidikan dan tujuan lembaga atau organisasi dapat tercapai

\section{Daftar Pustaka}

Azhar Arsyad. (2003). Pokok-pokok manajemen. Yogyakarta: Pustaka pelajar.

Suryobroto. (2004). Manajemen pendidikan di sekolah. Jakarta: Rineka Cipta. 
Budi Suhardiman. (2012). studi pengembangan kepala sekolah. Jakarta: Rineka Cipta.

Benowitz, ellen A. (2001). Principles of Management. New York: Hungry Minds.

Depdiknas (2005). Undang-undang RI Nomor 14, Tahun 2005, tentang Guru dan Dosen.

(2007). Peraturan Menteri Pendidikan Nasional, Nomor 16. Tahun 2007 tentang Standar Kaulifikasi Akademik dan Kompetensi guru.

(2003). Undang-undang RI Nomor 20, Tahun 2003, tentang Sistem Pendidi-an Nasional.

(2006). Direktorat Jendral manajemen Pendidikan Dasar dan Menengah Panduan Pengelolaan Taman Kanak-kanak.

Dwivedi, R.K. (2003). Organizational culture and performance. Oxford: Oxford University Press.

E. Mulyasa. (2005). Menjadi kepala sekolah profesional. Bandung: Remaja Rosdakarya.

Griffin, R.W. (1990). Management. Boston: Houghton Miffin Company.

Hani Handoko. (2003). Manajemen personalia dan manajemen sumber daya manusia. Yogyakarta: BPFE

Husaini Usman. (2008). Manajemen teori, praktik dan riset pendidikan. Jakarta: Bumi Aksara

(2006). Manajemen: Teori, praktik dan riset. Jakarta: Bumi Aksara.

(2010). Manajemen: teori praktik $\mathcal{E}$ riset pendidikan (edisi tiga). Jakarta: Bumi Aksara.

Kemendiknas. (2011). Direktorat pembinaan pendidikan anak usia dini. Dirjen PAUDNI. Petunjuk teknis penyelenggaraan taman kana-kanak

Lunenburg, F.C. \& Omstein, A.C. (2000). Educational administration: concepts and prcatices (3th ed). Balmont, CA: Wadsworth Thomson Learning.

Mulyasa. E. (2003). Menjadi kepala sekolah profesional. Bandung: Remaja Rosdakarya.

(2009). Manajemen Berbasis Sekolah. Bandung: PT Remaja Rosdakarya.

(2007). Manajemen berbasis sekolah: Konsep, strategi dan implementasi. Bandung:Remaja Rosdakarya offset.

M. Daryanto. (2005). Administrasi pendidikan. Jakarta: Rineka Cipta.

M. Manulang. (2004). Dasar-dasar manajemen. Yogyakarta: Gadjah Mada University Press.

Miles. B.M. \& Huberman, M.A. (1985). Qualitatif data analysis. London New Dehli Sage publication

Miftah Thoha. (2001). Perilaku organisasi konsep dasar dan aplikasinya. Jakarta: Gaung Persada Press.

Mitrani, A. (1995). Manajemen sumber daya manusia (Terjemahan). Jakarta: PT. Pustaka Utaman Grafiti.

Nana Sudjana (1996). Pembinaan dan pengembangan kurikulum di sekolah. Bandung: Sinar Biru.

Oemar Hamalik. (2006). manajemen pengembangan kurikulum. Bandung: Remaja Rosdakarya.

Reinhartz, J \& Beach, D.M. (2004). educational leadership changing school, changing roles. USA: Perason education, Inc.

Sugiyono. (2003). Metode penelitian Administrasi. Bandung: Alfabeta

Soejono. (2003). Metode penelitian. Suatu penelitian dan penerapan. Jakarta: Rineka Cipta

Soetopo, H, et all. (1984). Kepemimpinan pendidikan dan supervisi. Jakarta: Bina Aksara 
Sukanto Reksohadiprodjo. (2000). Dasardasar manajemen. Yogyakarta. BPEE UGM.

Sagala, S. (2009). Kemampuan profesional guru dan tenaga kependidikan. Bandung: Alfabeta.

Siswanto Sastrohadiwiryo. (2005). Manajemen tenaga kerja Indonesia: pendekatan administratif dan operasional. Jakarta: Bumi Aksara.

Siagaian, H. (1989). Administrasi pendidikan suatu pendekatan sistemik. Semarang: Satya Wacana.

Stoner, J.A.F, Freeman, R.E. \& Gilbert, D.R., JR. (1995). Management (6th ed). NewJersey: Pentice Hall, Inc.

Terry, G.R (1977). Principles of management. Homewood: Ricard D. Irwan Inc.

Wahdjosumidjo. (2005). kepemimpinan kepala sekolah: Tinjauan teoritik dan per- masalahannya. Jakarta: Raja Grafindo Persada.

Wahyudi. (2009). Kepemimpinan kepala sekolah: Dalam organisasi pembelajar (leraning organization). Bandung: Alfabeta.

Winardi (1990). Kepemimpinan dalam manajemen. Jakarta : Rinek Cipta

Yamin, H.M., \& Maisah. (2010). Standarisasi kinerja guru. Jakarta: Gaung Persada.

http://www.suarapembaharuan.com/Ne ws/1999/01/220199/OpEd, diakses 7 Mei 2012). Hlm. 1-2.

Yukl.G. (1994). Leadership in organizations. United States of America: Pretence Hall International. Inc. http://edukasi.kompas.comread/2 010/05/01/10111443/Pentingnya.Pendidik an.Karakter.Bangsa, diakses 7 Mei 2012). Hlm. 1-2 